\title{
DÜBLIN
}

Technological University Dublin

ARROW@TU Dublin

\section{Green Tea Extract as a Natural Antioxidant to Extend the Shelf-life of Fresh-cut Lettuce}

\author{
Catherine Barry-Ryan \\ Technological University Dublin, Catherine.Barryryan@tudublin.ie \\ Ana Belen Martin-Diana \\ Technological University Dublin, anabelen.martindiana@tudublin.ie \\ Daniel Rico \\ Technological University Dublin, daniel.rico@tudublin.ie
}

Follow this and additional works at: https://arrow.tudublin.ie/schfsehart

\section{Recommended Citation}

Barry-Ryan,C., Martin-Diana,A.,Rico,D. (2008) Green tea extract as a natural antioxidant to extend the shelflife of fresh-cut lettuce. Innovative Food Science and Emerging Technologies, 9 (2008) 593-603.

doi:10.1016/j.ifset.2008.04.001

This Article is brought to you for free and open access by the School of Food Science and Environmental Health at ARROW@TU Dublin. It has been accepted for inclusion in Articles by an authorized administrator of ARROW@TU Dublin. For more information, please contact arrow.admin@tudublin.ie, aisling.coyne@tudublin.ie, gerard.connolly@tudublin.ie.

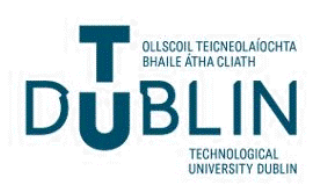




\title{
Green tea extract as a natural antioxidant to extend the shelf-life of fresh-cut lettuce
}

\author{
Innovative Food Science and Emerging Technologies 9 (2008) 593-603
}

\author{
A. B. Martín-Diana, D. Rico, Catherine Barry-Ryan
}

School of Food Science and Environmental Health, Dublin Institute of Technology (DIT), Cathal Brugha

Street, Dublin 1, Ireland

Keywords: Green tea, Camellia sinensis L., Fresh-cut lettuce, Polyphenols, Browning

\section{A B STRACT}

Green tea extract (GT) was evaluated as a preservative treatment for fresh-cut lettuce. Different quality markers, e.g. respiration, browning, ascorbic acid and carotenoid content were evaluated. GT concentration $(0.25,0.5$ and $1 \mathrm{~g} 100 \mathrm{~mL}-1)$ and temperature $\left(20^{\circ} \mathrm{C}\right.$ and $\left.50^{\circ} \mathrm{C}\right)$ were tested. Optimal GT treatment $(0.25 \mathrm{~g}$ $100 \mathrm{~mL}-1$ at $\left.20^{\circ} \mathrm{C}\right)$ was compared with chlorine $\left(120 \mathrm{ppm}\right.$ at $\left.20^{\circ} \mathrm{C}\right)$. High GT concentrations $(0.5 \mathrm{~g} 100 \mathrm{~mL}-1$ and $1.0 \mathrm{~g} 100 \mathrm{~mL}-1$ ) maintained better prevent ascorbic acid and carotenoid loss than $0.25 \mathrm{~g} 100 \mathrm{~mL}-1 \mathrm{GT}$ and chlorine. GT increased browning of samples, probably due to the content of polyphenols of the treatment; the use of heat-shock reduced this negative effect. GT and heat-shock combined also showed negative effects, reducing the antioxidant content (ascorbic acid and carotenoids). No significant differences were observed between chlorine and optimal GT $\left(0.25 \mathrm{~g} 100 \mathrm{~mL}-1\right.$ at $\left.20^{\circ} \mathrm{C}\right)$ in browning appearance and sensory properties. GT better kept the antioxidant activity of the samples than chlorine.

Industrial relevance: An alternative treatment for minimally processed lceberg lettuce is tested, based on its antioxidant capacity. Minimally processed industry is constantly looking for new treatments to avoid the use of chlorine which is a standard at the moment.

\section{Introduction}

Green tea (Camellia sinensis L.) is a popular beverage and it has been reported to exert beneficial effects on several life-style related diseases: chemopreventive, anticarcinogenic, antiatherogenic, antioxidant and antimicrobial activities (Si et al., 2006; McKay \& Blumberg, 2002; Rietveld \& Wiseman, 2003; Cooper, Morre \& Morre, 2005). The ability to inhibit food-borne pathogens such as Escherichia coli, Salmonella typhimurium, Listeria monocytogenes, Staphylococcus aureus, and Campylobacter jejuni has been reported for different varieties of tea or tea extracts, including Oolong, Jasmine and Black (Si et al., 2006; Hamilton-Miller, 1995; Hamilton-Miller \& Shah, 2005; Yeo, Ahn, Lee, Lee, Park \& Kim, 1995).

However, results showing antimicrobial activity of tea extract components against bacterial pathogens have been inconsistent due to the variability of the methods used (e.g. different varieties of tea, different processing and extraction procedures) and the mechanisms of action described in the literature remain controversial (Si et al., 2006).

Green tea is an excellent source of polyphenols, which are natural antioxidants that can be used as alternatives to synthetic antioxidants as they are typically less harmful than synthetic ones and appears to have an equivalent effect upon the inhibition of oxidation (Cao, Sofic \& Prior, 1996). These antioxidants, which inhibit the oxidation of organic molecules, are very important, not only for living systems and their defence against oxidative stress but also for food preservation
(Masuda et al., 2003). Phenolic antioxidants interrupt the propagation of the free radical autoxidation chain by contributing a hydrogen atom from a phenolic hydroxyl group, with the formation of a relatively stable free radical that does not initiate or propagate further oxidation processes (Kaur \& Kapoor, 2001).

Fresh-cut vegetable industry $(\sim 10 \%$ p.a. $)$ has undergone an important growth due to the increasing demand for fresh, healthy and convenient foods. A substantial portion of vitamins and minerals in the diet comes from fruit and vegetable consumption (Klein, 1987). There is mounting evidence to support the alleviation of many degenerative diseases including cardiovascular disease, cancer and ageing by the consumption of fruit and vegetables (Kaur \& Kapoor, 2001 ). These beneficial health effects of fruit and vegetables have been attributed to the presence of antioxidants that act as receptors of free radicals. Ascorbic acid and $\beta$-carotene are the antioxidants present in the greatest quantities in fruit and vegetables and usually are destroyed after processing or decontamination procedures.

Consumers have also become more critical to the use of artificial additives in order to preserve food or enhance characteristics such as colour, flavour and nutritional value (Bruhn, 2000). Ohlsson (1994) suggests that minimal processing techniques have emerged to meet the challenge of replacing traditional methods of preservation while retaining nutritional and sensory quality. RTU vegetables typically involve peeling, slicing, dicing or shredding prior to packaging and storage (Barry-Ryan \& O'Beirne, 1999). The International Fresh-cut Produce Association (IFPA) defines fresh-cut products as fruit or vegetables that have been trimmed and/or peeled and/or cut into 


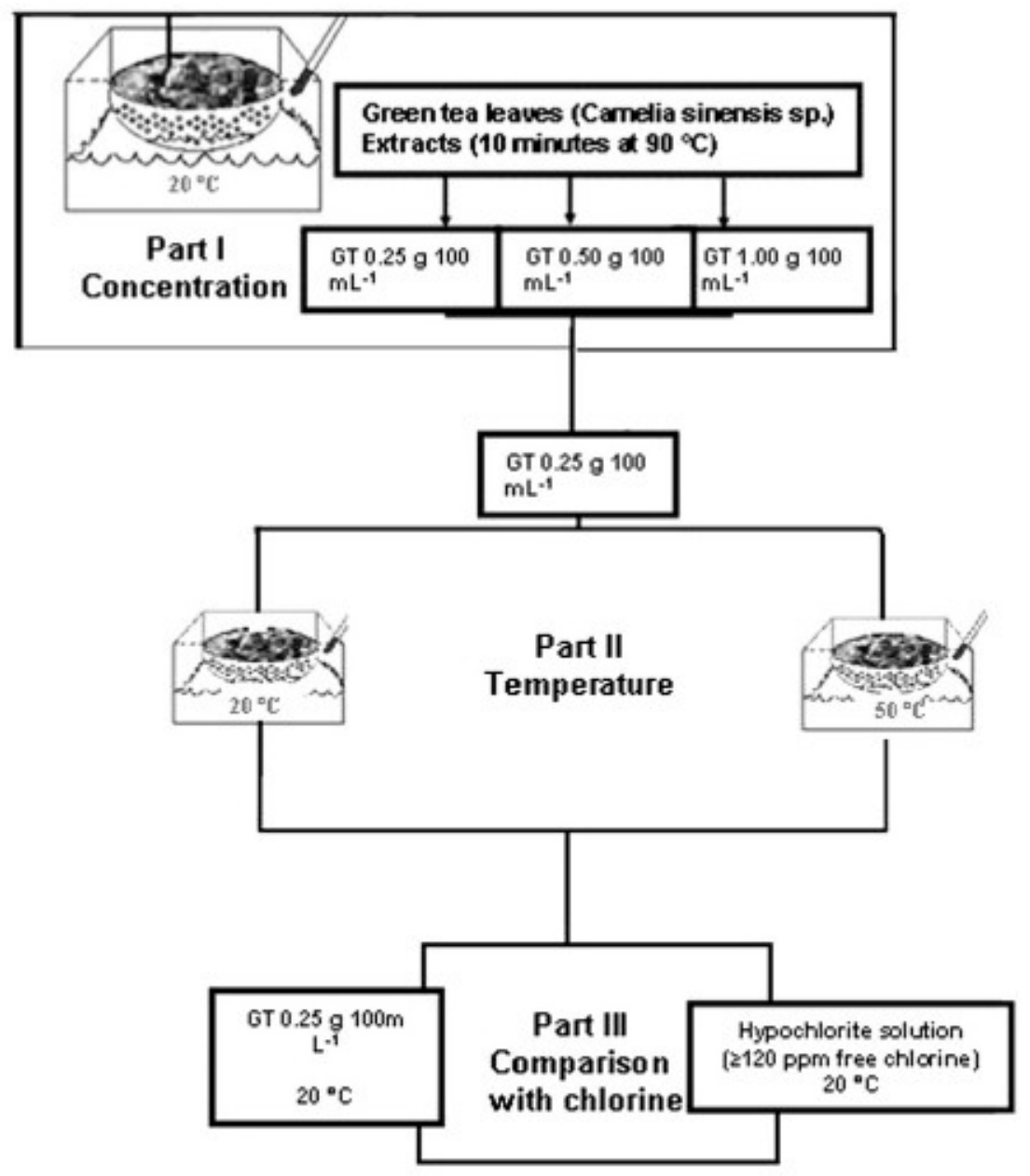

Fig. 1. Experimental design for the testing of Green tea extracts treatments on fresh-cut lettuce.

$100 \%$ usable product that is bagged or pre-packaged to offer consumers high nutrition, convenience, and flavour while still maintaining its freshness (Lamikanra, 2002).

It is well-known that processing of vegetables promotes a faster physiological deterioration, biochemical changes and microbial degradation of the product even when only slight processing operations can be used (O'Beirne \& Francis, 2003), which may result in degradation of the colour, texture and flavour (Kabir, 1994; Varoquaux \& Wiley, 1994). While conventional food-processing methods extend the shelf-life of fruit and vegetables, the minima processing to which fresh-cut fruit and vegetables are subjected renders products highly perishable, requiring chilled storage to ensure a reasonable shelf-life (Garcia \& Barret, 2002).

The vast majority of fresh minimally processed produce manufacturers use chlorine in washing and decontamination procedures (Seymour, 1999). There is controversy about the formation of carcinogenic chlorinated compounds in water (chloramines and trihalomethanes), calling into question the use of chlorine (Wei et al., 1995)

The current concern associated with chlorine outlines the need to find new alternatives for preservation of minimally processed vegetables. Traditional and novel technologies for maintaining quality while inhibiting undesired microbial growth are being investigated, driven by an increasing demand from the industry and consumers. These include use of temperature blanching/steamer (Abreu, Beirão-da-Costa, Gonçalves, Beirão-da-Costa \& Moldão-Martins, 2003; Martín-Diana et al., 2007a; Rico et al., 2008a,b); short thermal shocks (Loaiza-Velarde, Mangrich, Campos-Vargas, \& Saltveit, 2003; Martín-Diana et al., 2005a;
Koukounaras, Diamantidis \& Sfakiotakis, 2008); organic acids (Rosen \& Kader, 1989; Agar, Massantini, Hess-Pierce, \& Kader, 1999; Luna-Guzmán \& Barrett, 2000; Martín-Diana et al., 2005b; Martín-Diana et al., 2007b), irradiation (Allende \& Artes, 2003a; Han et al., 2004), modified atmosphere packaging (Kato-Noguchi \& Watada, 1997, Allende \& Artes, 2003b), ozone (García, Mount \& Davidson, 2003; Zhang, Zhaoxin, Zhifang \& Xiang, 2005; Rico, Martín-Diana, Frías, Henehan \& Barry-Ryan, 2006), electrolysed water (Izumi, 1999; Koseki, Yoshida, Kamitani, Isobe \& Itoh, 2004; Park, Hung, Doyle, Ezeike \& Kim, 2001; Rico et al., 2008a,b), electric pulses (Giner et al., 2000), edible coating (Molnar-Perl \& Friedman, 1990; Guilbert, Gontard, \& Gorris, 1996; Son, Moon, \& Lee, 2001) among others.

During the last years a special renewed interest in the use of natural products as decontaminants has been noticed. Research and commercial applications have shown that natural antimicrobials could replace traditional sanitizing agents (Graham,1997; Cherry,1999; Martín-Diana, Ricoet al., 2006). Green tea has been used to extend the shelf-life of dryfermented sausage (Bozkurt, 2006), enrich candy jellies (GramzaMichalowska \& Regula, 2007) and cooked pork patties (Nissen, Byrne, Bertelsen \& Skibsted, 2004). However, only a few studies can be found on the use of Green tea in fresh-cut fruits or vegetables.

Due to the lack of information regarding the use of Green tea in minimally processed vegetables, the objective of this research was to evaluate its ability to extend the shelf-life of fresh-cut lettuce. Quality markers, mainly indicators of respiration, browning, sensory and nutritional parameters were used to optimise the Green tea extract treatment conditions (concentration and temperature) and to compare its effect on fresh-cut lettuce quality with chlorine (standard treatment). 


\section{Materials and methods}

\subsection{Sampling and experimental design}

The experiments were carried out between December 2004 and June 2005. All procedures were performed in a food-processing room at $20^{\circ} \mathrm{C}$. Each batch consisted of $\sim 18-25 \mathrm{~kg}(\sim 55-65$ heads of lettuce of $\sim 450 \mathrm{~g}$ each). For colour and texture analyses all pieces in the assigned bag ( 20 to 25 approx.) were analysed individually to minimise error due to product variability. For sensory analysis, samples from the whole storage bag were analysed. For destructive analysis (enzymes, ascorbic acid, carotenoids and $\mathrm{pH}$ ) samples were taken from a pool of all the pieces in a storage bag.

The experimental design was divided in to three parts (Fig. 1): two-step optimisation of Green tea extract (GT) treatment conditions to extend the quality and nutritional value of fresh-cut lettuce (Parts I and II) and comparison of GT and chlorine treatments (Part III).

Preliminary sensory studies using GT concentrations from 0 to $5 \mathrm{~g}$ $100 \mathrm{~mL}-1$ vs. $120 \mathrm{ppm}$ chlorine as control were carried out in fresh-cut lettuce. Sensory results showed that it was necessary to use at least concentrations of $0.25 \mathrm{~g} 100 \mathrm{~mL}-1$ and a maximum of $1 \mathrm{~g} 100 \mathrm{~mL}-1$ to obtain samples considered as acceptable during the shelf-life (10 days).

The optimisation of GT concentration (Part I) was done using concentrations $(0.25,0.5$ and $1.0 \mathrm{~g} 100 \mathrm{~mL}-1)$. Part II consisted of a comparative analysis using GT treatments at a concentration obtained from the optimisation step (Part I) at two temperatures: 20 and $50{ }^{\circ} \mathrm{C}$. The temperatures were selected to analyse the combined effect of heat-shock and GT. The two temperatures were selected based on previous research (Martin-Diana et al., 2005a,b,c). The last part of the experiment (Part III) was carried out in order to compare the optimal GT conditions obtained in the two previous steps (Part I and II) with an industrial standard treatment.

\subsection{Raw material}

Iceberg lettuce (Lactuca sativa sp.) was grown in Ireland and purchased from a local supplier. The lettuce was brought to the laboratory within $24 \mathrm{~h}$ after harvest and stored in cardboard boxes, in bulk and unwrapped at $4{ }^{\circ} \mathrm{C}$ until processing.

\subsection{Processing (washing and packaging procedure)}

Lettuce was prepared according to safety statements and recommendations (Beuchat \& Ryu, 1997; Beuchat, 1998). The two outer leaves were removed and the heads cored with a stainless steel knife. The lettuce was cut in halves and each half was further cut into four pieces.

Washing treatments consisted of immersion of the fresh-cut lettuce in the treatment solution. Dried and ground Green tea (C. sinensis L.) leaves

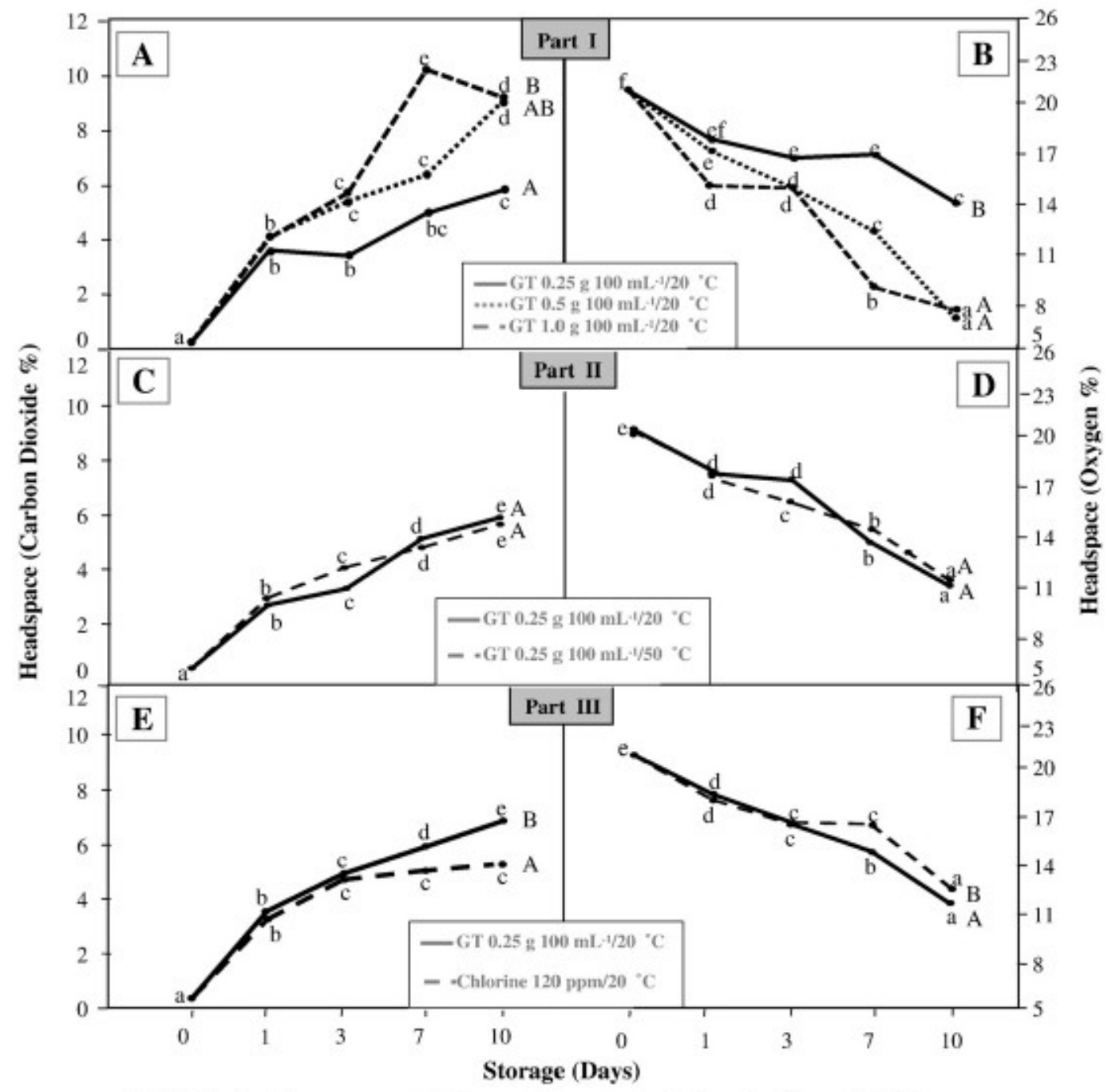

*Points designated on any curve by the same letter are not significantly different ( $p>0.05$ ) 
were brewed for $5 \mathrm{~min}$ in distilled water at $90^{\circ} \mathrm{C}$ at different concentrations $(0.25 \mathrm{~g} 100 \mathrm{~mL}-1,0.5 \mathrm{~g} 100 \mathrm{~mL}-1$ and $1 \mathrm{~g} 100 \mathrm{~mL}-1$ with a content in total phenolics respectively of 350,700 and $1260 \mathrm{mg}$ of gallic acid per litre of infusion). The obtained extracts were filtrated two times trough a Whatman No. 1 filter paper. Chlorinated water was prepared by adding sodium hypochlorite ( $\geq 120 \mathrm{ppm}$ available chlorine) to distilled water to obtain a $120 \mathrm{ppm}$ free chlorine solution $(\mathrm{pH} \sim 8)$. Free chlorine concentration in the washing solution was determined with the DPD method, using a DREI/2000 spectrometer with appropriate AccuVac® pillows (Hach Company, Loveland, Colorado, USA)

For all treatments the solutions were prepared using distilled water stored at selected temperatures according to the experimental design. The cut produce was placed in a basket and immersed with agitation in the solution ( $100 \mathrm{~g}$ vegetable product per litre) for $1 \mathrm{~min}$ and subsequently dried for 5 min using an automatic salad spinner.

To minimise product heterogeneity, processed vegetables were pooled, mixed and subsequently packaged in bags $(200 \times 320 \mathrm{~mm})$ of oriented polypropylene (Amcor Flexibles Europe-Brighouse, United Kingdom). Film permeabilities to oxygen and carbon dioxide were $\sim 12,000$ and $\sim 13,000\left(\mathrm{~mL} \mathrm{~m}-2\right.$ day -1 atm- 1 at $\left.5{ }^{\circ} \mathrm{C}\right)$ respectively. Each package contained $\sim 100 \mathrm{~g}$ of the product. The packages were chilled in a blast freezer set at $0{ }^{\circ} \mathrm{C}$ for 2 min before being sealed to avoid water condensation during storage $\left(10\right.$ days at $\left.4{ }^{\circ} \mathrm{C}\right)$.
2.4.3.3. Browning-related enzymes (peroxidase (POD) E.C.1.11.1.7 and polyphenol oxidase (PPO) E.C.1.10.3.1.). Both enzymes were assayed in homogenates that were prepared as follows: $10 \mathrm{~g}$ of lettuce was placed in a polytron homogeniser (Polytron model PT 3000) in a 1:2 (w:v) ratio with $0.5 \mathrm{M}$ phosphate buffer $\mathrm{pH} 6.5$ containing $50 \mathrm{~g} \mathrm{~L}-1$ polyvinylpyrrolidone. Homogenisation was carried out two times at $4{ }^{\circ} \mathrm{C}$, and $5500 \mathrm{rpm}$, for 1 min each time with a break of 3 min between homogenisations in order to avoid excessive heating of the sample. The homogenate was then centrifuged at $12,720 \times \mathrm{g}$ for $30 \mathrm{~min}$ at $4{ }^{\circ} \mathrm{C}$. It was filtered through one layer of crepe bandage. The resulting crude extract was used without further purification. All the extracts were stored at $44^{\circ} \mathrm{C}$ in the dark and used immediately.

POD activity was assayed spectrophotometrically. The reaction mixture contained $0.2 \mathrm{~mL}$ of extract and $2.7 \mathrm{~mL}$ of $0.05 \mathrm{M}$ phosphate buffer $\mathrm{pH} 6.5$ containing $100 \mu \mathrm{L}$ of hydrogen peroxide $(1 \mathrm{~mL} / \mathrm{L} \mathrm{v} / \mathrm{v})$ as an oxidant and $200 \mu \mathrm{L}$ of $\mathrm{p}$-phenylendiamine as hydrogen donor. The oxidation of p-phenylendiamine was monitored at $485 \mathrm{~nm}$ and 25 $25^{\circ} \mathrm{C}$. An enzyme activity unit was defined as an increment of 0.1 in absorbance per minute. PPO activity was assayed spectrophotometrically by a modified method based on Galeazzi, Sgarbieri and Constantinides (1981) and Tan and Harris (1995). The reaction mixture contained $0.1 \mathrm{~mL}$ crude extract and $2.9 \mathrm{~mL}$ substrate solution $(0.020 \mathrm{~mol} / \mathrm{L}$ catechol in $0.05 \mathrm{~mol} / \mathrm{L}$ phosphate buffer, $\mathrm{pH} 6.5)$. The rate of catechol oxidation was followed at $400 \mathrm{~nm}$ for $2 \mathrm{~min}$ at $25^{\circ} \mathrm{C}$. An enzyme activity unit was defined as an increase of 0.1 in absorbance per minute. Three independent trials were carried out. All the enzymatic measurements were carried out in duplicate.

\subsection{Shelf-life analysis}

The objective was to study the effect of GT on the quality of freshcut lettuce. Respiration, $\mathrm{pH}$, browning appearance (browning-related enzymes, colour and potential browning) and nutritional changes (ascorbic acid and carotenoids) were evaluated as indicators of shelflife. Shelf-life is defined as the length of time at which the vegetable can maintain the appearance, safety and antioxidant content that appeals to the consumer (Delaquis, Stewart, Toivonen \& Moyls, 1999), therefore markers were monitored throughout the storage (10 days).

\subsubsection{Headspace analysis}

A Gaspace analyser (Systech Instruments, UK) was used to measure levels of $\mathrm{CO}_{2}$ and $\mathrm{O}_{2}$ during storage. Gas extractions were performed with a hypodermic needle, inserted through an adhesive septum previously fixed to the bags, at a flow rate of $30 \mathrm{~mL} / \mathrm{min}$ for $10 \mathrm{~s}$. The accuracy is in percentage of readings: $\pm 0.5 \%$ below $10 \%$ and $\pm 0.1 \%$ above $10 \%$ for $\mathrm{O}_{2} ; \pm 0.1 \%$ below $1 \%, \pm 0.2 \%$ between $1 \%$ and $10 \%$ and $\pm 2 \%$ above $10 \%$ for $\mathrm{CO}_{2}$. Three bags per treatment and batch were monitored throughout the storage.

2.4.2. $\mathrm{pH}$. Ten grams sample of lettuce tissue was blended for $2 \mathrm{~min}$ in $20 \mathrm{~mL}$ of deionised water. The $\mathrm{pH}$ of the slurry was measured at room temperature using an Orion research $\mathrm{pH}$-meter.

\subsubsection{Browning}

2.4.3.1. Colour measurement. Colour was quantified using a colorimeter (Minolta, Model CM-3600d, UK). A lettuce piece was place directly on the colorimeter sensor (3.5 cm of diameter) and measured; 20-30 measurements were taken per treatment and day. The instrument was calibrated with a white tile standard $\left(\mathrm{L}^{*}=93.97, \mathrm{a}^{*}=-0.88\right.$ and $\left.b^{*}=1.21\right)$ and a green tile standard ( $\left.L 8=56.23, a^{*}=-21.85, b^{*}=8.31\right)$ under D65 luminosity conditions. The $a^{*}$ parameter measures the degree of red $(+a)$ or green $\left(-a^{*}\right)$ colour and the $b^{*}$ parameter measures the degree of yellow $(+b)$ or blue $\left(-b^{*}\right)$ colour.

2.4.3.2. Potential browning. Potential browning was measured according to the methodology of Viňa and Chaves (2006). Ten grams of tissue frozen and crushed was treated with ethanol for $60 \mathrm{~min}$ and then centrifuged at $6000 \mathrm{rpm}$ at $10^{\circ} \mathrm{C}$ for $10 \mathrm{~min}$, retaining the supernatants. After a further amount of ethanol was added to bring the final volume to $25 \mathrm{~mL}$. Absorbance at $320 \mathrm{~nm}$ was measured on aliquots of these extracts The results were expressed as absorbance units (AU) g- 1 fresh tissue.

2.4.4. Sensory analysis. Analytical-descriptive tests were used to evaluate the sensory quality attributes of fresh-cut lettuce prepared by different washing treatments. The panel, which consisted of 10 judges aged 20-30 years with sensory evaluation experience, were trained in discriminate evaluation of fresh-cut tissue. Panellists were required to score changes in total browning, photosynthetic browning, vascular browning and fresh appearance. Before the start of the sensory experiments, panel members were familiarised with the product and scoring methods. This consisted of demonstration exercises involving examination of packs at different levels of deterioration and agreeing appropriate scores. When the panel members had become familiar with the test facilities and scoring regime, they were invited to score samples. This procedure was repeated several times until a level of consistency in scoring was obtained. The same packages were scored during the entire test for sensory analysis (10 days), due to the high variability of the product. During this stage, the samples were presented to the panel to evaluate and measure the reproducibility of the judge's answers and their capability in discriminating among samples. During the analyses, samples were presented in randomized order to minimise possible carry-over effects.

Fresh-cut lettuce was evaluated for appearance using a ten point numerical rating scale, where: (I) General Browning, where $1=$ nothing, $5=$ moderate and $10=$ a lot (severe browning); (II) Photosynthetic Browning, where $1=$ nothing, $5=$ moderate and $10=$ a lot (severe browning); (III) Vascular Browning, where $1=$ nothing, $5=$ moderate and $10=$ a lot (severe browning); (IV) Fresh appearance, where $1=$ poor/no fresh appearance, $5=$ moderate and $10=$ very good/fresh appearance.

The results of the sensory analysis were reported as means of three separate trials. Data analysis was collected using Compusense ${ }^{\circledR}$ Five software (Release 4.4, Ontario, Canada).

\subsubsection{Nutritional markers}

24.5.1. Ascorbic acid. Ascorbic acid determination was carried out according to the 2,6,-dichlorolindophenol method recommended by AOAC (1995) for the analysis of Vitamin $C$ in fruits and juices. grams of fresh-cut was homogenised with $50 \mathrm{~mL}$ of aceticmethaphosphoric acid at low speed -(in order to avoid foaming) for 

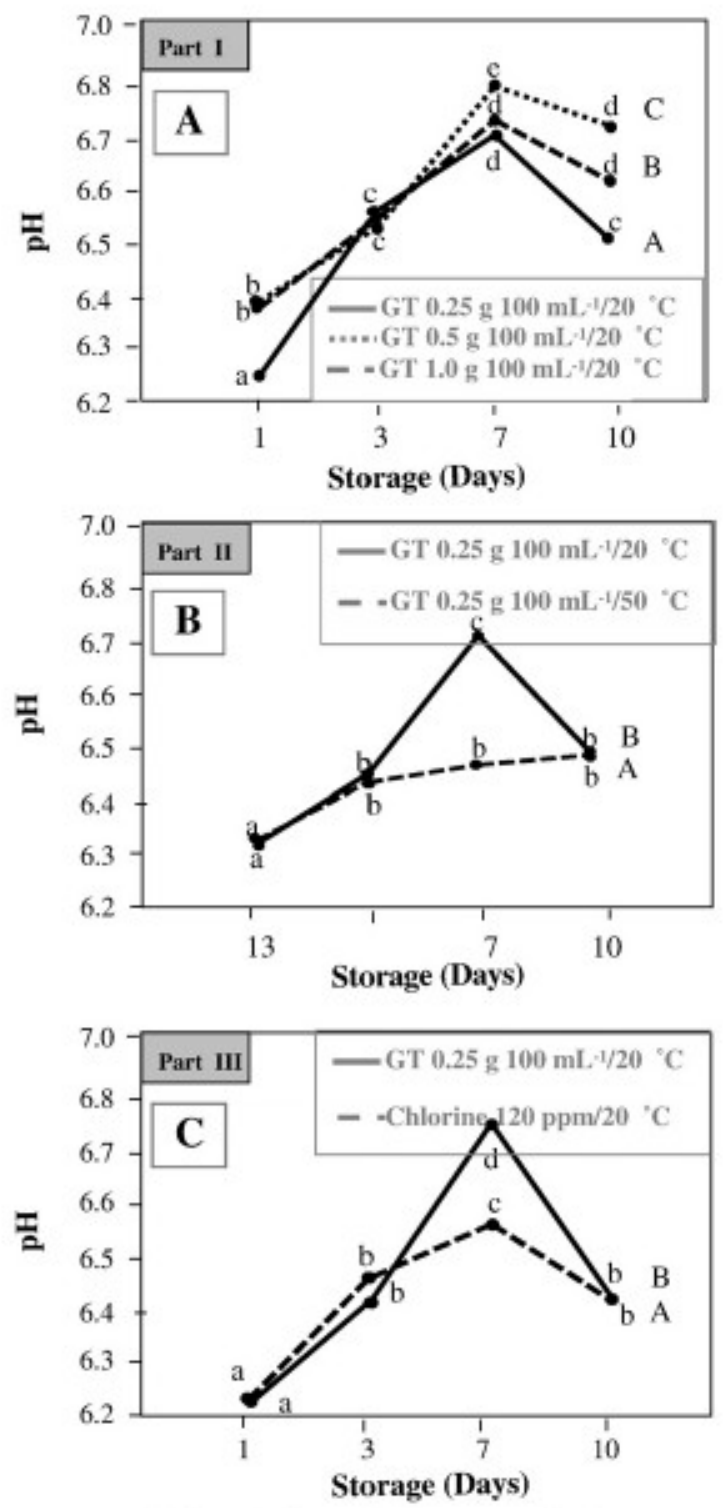

*Points designated on any curve by the same letter are not significantly different $(\mathrm{p}>0.05)$

Fig. 3. Changes in $\mathrm{pH}$ of fresh-cut lettuce stored at $4{ }^{\circ} \mathrm{C}$ for 10 days. Part I: GT at different concentrations $\left(0.25,05\right.$ and $1 \mathrm{~m} 100 \mathrm{~mL}-1$ at $20^{\circ} \mathrm{C}$ ) Part ll. $0.25 \mathrm{~g} 100 \mathrm{~L}-1 \mathrm{GT}$ at $20^{\circ} \mathrm{C}$ and $50^{\circ} \mathrm{C}$. Part III: $0.25 \mathrm{~g} 100 \mathrm{~mL}-1 \mathrm{GTE}$ at $20^{\circ} \mathrm{C}$ and $120 \mathrm{ppm}$ chlorine at $20^{\circ} \mathrm{C}$.

3 min at $4{ }^{\circ} \mathrm{C}$ in darkness. -The homogenate was filtered and aceticmethaphosphoric added up to $100 \mathrm{~mL}$. Aliquots of $10 \mathrm{~mL}$ were titrated rapidly in triplicate, using aceticmethaphosphoric acid as a blank. The results were expressed as $\mathrm{mg}$ ascorbic acid in $\mathrm{g}$ of sample.

mg ascorbic acid/g sample $=(X-B) *(F / E)^{*}(V / Y)$

where $\mathrm{X}$ is $\mathrm{mL}$ 2,6,-dichlorolindophenol (DCPIP) used to obtain a permanent pink colour which persists more than $5 \mathrm{~s}, \mathrm{~B}$ is the DCPIP volume used for the control (blank), $F^{*}$ is the DCPIP factor $(F=2 \mathrm{mg}$ ascorbic acid (standard) $\mathrm{mL}-1$ DCPIP), $E$ is $\mathrm{g}$ of sample $(20 \mathrm{~g}), \mathrm{V}$ is the final volume prepared $(100 \mathrm{~mL})$ and $\mathrm{Y}$ is $\mathrm{mL}$ titrated $(10 \mathrm{~mL})$.

2.4.5.2. Total carotenoids. Total carotenoids were extracted in the dark by homogenising lettuce tissue $(5 \mathrm{~g})$ with $30 \mathrm{~mL}$ of an acetone/ ethanol (50:50 v:v) solution, containing $200 \mathrm{mg} \mathrm{L}-1$ of butylated hydroxytoluene (BHT). The homogenate was filtered under suction in a buchner funnel and washed with acetone/ethanol solvent until colourless. Filtrate was adjusted to $100 \mathrm{~mL}$ volume with acetone/ ethanol. An aliquot was placed in a $1 \mathrm{~cm}$ cuvette and its absorbance was measured at $470 \mathrm{~nm}$. Total carotenoids ( $\mathrm{mg} / \mathrm{g}$ of sample) were calculated as described by Gross (1991).

\subsection{Statistical analysis}

Analysis of ANOVA (Multifactor and one-way) was used to find differences between treatments, storage and interaction of both factors for each one of the variables studied. Means were compared by significant difference (LSD) test, at a significance level $p=0.05$ using the Statgraphics software (version 2.1; Statistical Graphics Co. Rockville, USA). Three independent trials were carried out.
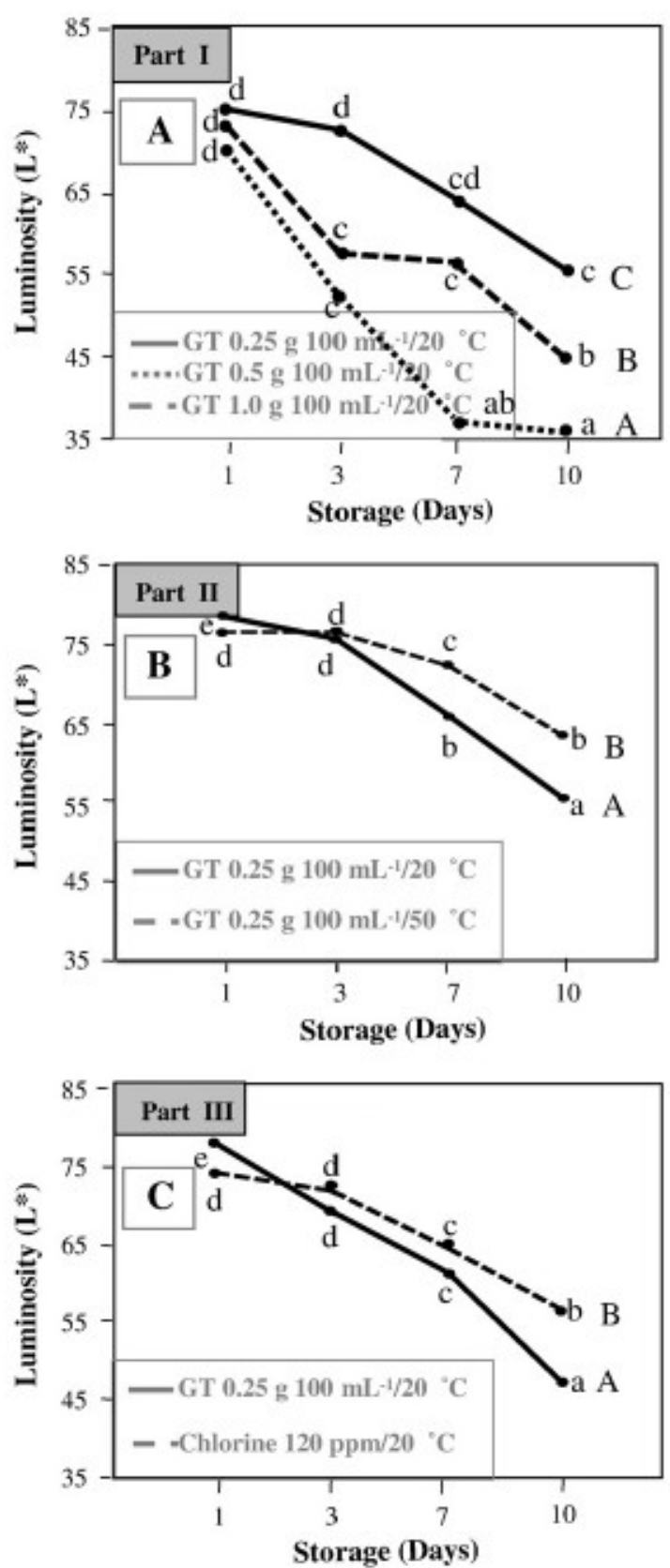

*Points designated on any curve by the same letter are not significantly different $(p>0.05)$

Fig. 4. Changes in luminosity (CIE L a b parameters) in fresh-cut lettuce stored at $4{ }^{\circ} \mathrm{C}$ for 10 days. Part I: GT at different concentrations $\left(0.25,05\right.$ and $1 \mathrm{~g} 100 \mathrm{~mL}-1$ at $20^{\circ} \mathrm{C}$ ). Part II: $0.25 \mathrm{~g} 100 \mathrm{~mL}-1 \mathrm{GT}$ at $20^{\circ} \mathrm{C}$ and $50{ }^{\circ} \mathrm{C}$. Part III: $0.25 \mathrm{~g} 100 \mathrm{~mL}-1 \mathrm{GT}$ at $20^{\circ} \mathrm{C}$ and $120 \mathrm{ppm}$ chlorine at $20^{\circ} \mathrm{C}$ 
3. Results and discussion

\subsection{Headspace}

The package headspace was monitored over 10 days of storage. Carbon dioxide and oxygen content, starting at atmospheric values, significantly $(p<0.05)$ changed regardless of the treatment. GT concentration (Fig. 2A,B) affected the respiration rate of the samples. Significantly ( $p$ b 0.05) lower oxygen and higher carbon dioxide levels were observed in samples treated with GT concentrations ( 0.5 and

$1.0 \mathrm{~g} \mathrm{~L}-1)$ compared to those treated with the lowest concentration $(0.25 \mathrm{~g} \mathrm{~L}-1)$. Higher GT concentrations produced an increase in the
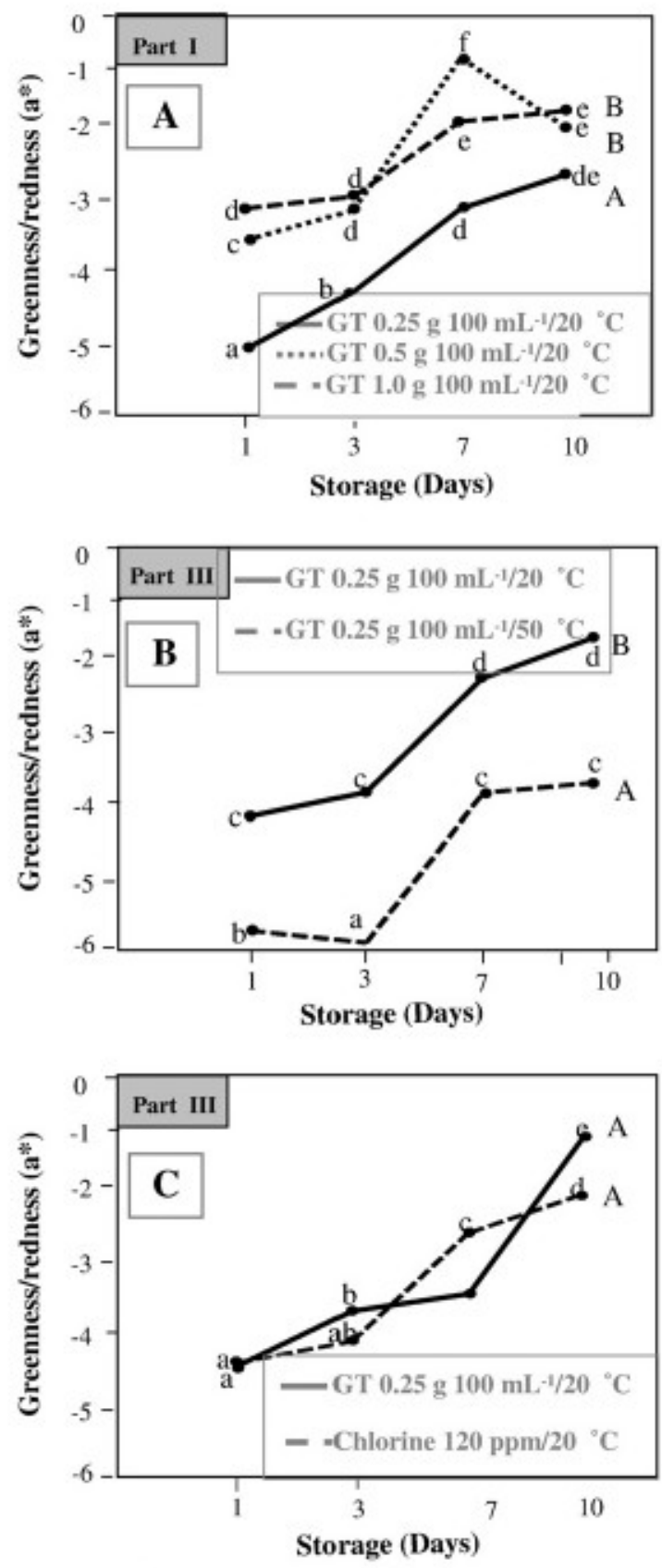

*Points designated on any curve by the same letter are not significantly different $(\mathrm{p}>0.05)$

Fig. 5. Changes in a (CIE L a b parameters) in fresh-cut lettuce stored at $4{ }^{\circ} \mathrm{C}$ for 10 days. Part I: GT at different concentrations $\left(0.25,05\right.$ and $1 \mathrm{~g} 100 \mathrm{~mL}-1$ at $\left.20^{\circ} \mathrm{C}\right)$. Part II: $0.25 \mathrm{~g} 100 \mathrm{~mL}-1 \mathrm{GT}$ at $20^{\circ} \mathrm{C}$ and $50^{\circ} \mathrm{C}$. Part III: $0.25 \mathrm{~g} 100 \mathrm{~mL}-1 \mathrm{GT}$ at $20^{\circ} \mathrm{C}$ and $120 \mathrm{ppm}$ chlorine at $20^{\circ} \mathrm{C}$.
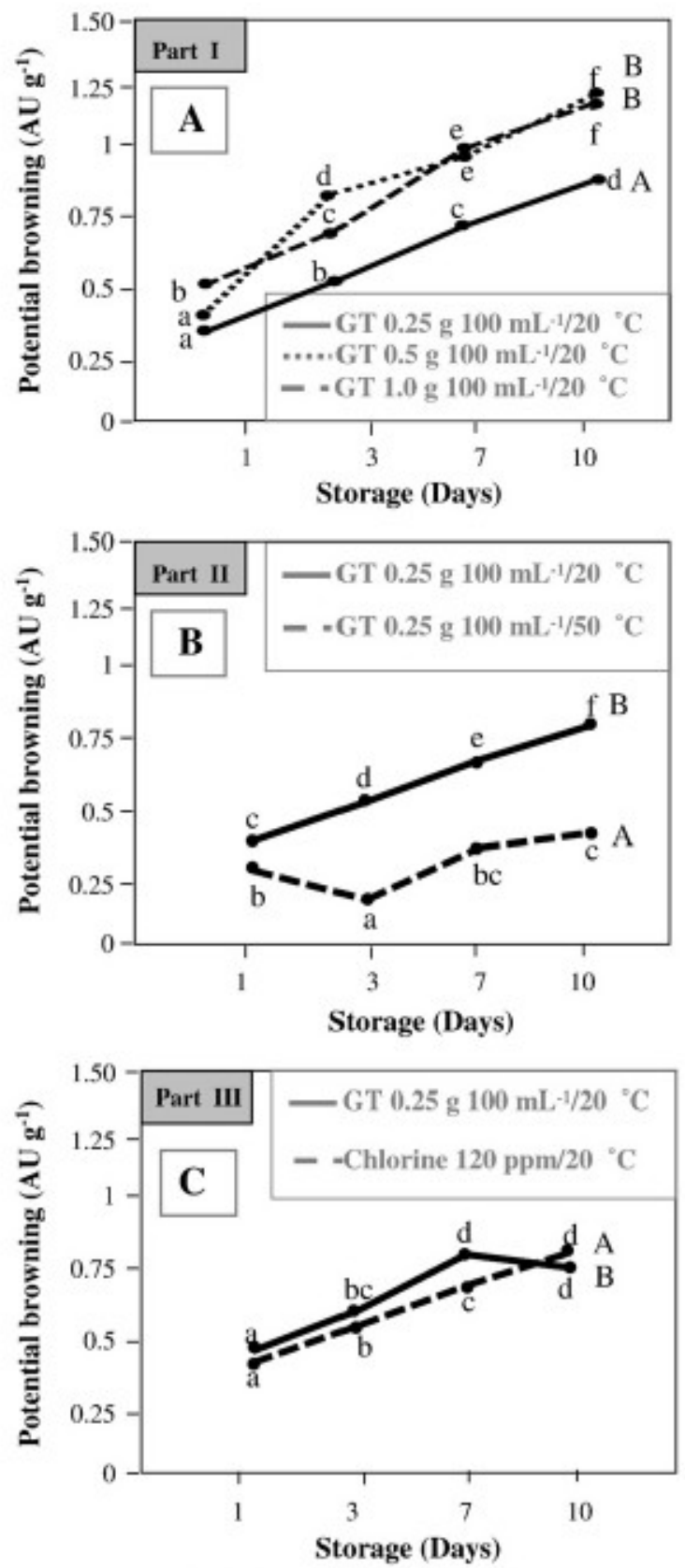

*Points designated on any curve by the same letter are not significantly different ( $p>0.05$ )

Fig. 6. Changes in potential browning (AU g-1) in fresh-cut lettuce stored at $4{ }^{\circ} \mathrm{C}$ for 10 days. Part I: GT at different concentrations $\left(0.25,05\right.$ and $1 \mathrm{~g} 100 \mathrm{~mL}-1$ at $\left.20^{\circ} \mathrm{C}\right)$. Part II: $0.25 \mathrm{~g} 100 \mathrm{~mL}-1 \mathrm{GT}$ at $20^{\circ} \mathrm{C}$ and $50^{\circ} \mathrm{C}$. Part III: $0.25 \mathrm{~g} 100 \mathrm{~mL}-1 \mathrm{GT}$ at $20^{\circ} \mathrm{C}$ and $120 \mathrm{ppm}$ chlorine at $20^{\circ} \mathrm{C}$.

respiration rate, maybe related to a higher stress caused by the more concentrated treatments (Surjadinata \& Cisneros-Zevallos, 2003). As indicated by Saltveit (2001) for fresh produce subjected to heat-shock for less than $2 \mathrm{~min}$, treatment temperature (Fig. 2C,D) did not show any effect on the oxygen and carbon dioxide concentrations, results in agreement with previous work of the authors (Martin-Diana et al., $2005 b)$. Headspace composition was significantly $(p<0.05)$ different in samples treated with the optimised GT treatment $(0.25 \mathrm{~g} 100 \mathrm{~m} \mathrm{L-1}$, $20{ }^{\circ} \mathrm{C}$ ) and those treated with chlorine (Fig. 2E,F). These indicated that the GT treatment increased respiration of the produce in comparison with chlorine, probably indicating a higher stress caused by the GT treatment. 
In all cases, the levels of oxygen were above $6 \%$, avoiding hypoxic atmosphere conditions which favour the fermentative processes that cause the formation of acetaldehyde and the appearance of offflavours compounds (Kays, 1991; Beaudry, 1999). In general, the highest respiration rates were observed in samples treated with the intermediate and high concentrations $(0.5$ and $1.0 \mathrm{~g} 100 \mathrm{~mL}-1) \mathrm{GT}$, indicating a possible negative effect of increased stress with the use of an excessively high concentration of Green tea.

3.2. $\mathrm{pH}$

Changes in $\mathrm{pH}$ were monitored in all the samples through the 10-day storage (Fig. 3, Part I, Part II and Part III). A significant increase in $\mathrm{pH}$ was observed for all the samples, with a peak at day 7 followed by a decrease at day 10. Different authors (King \& Bolin, 1989; Jacxsens

1000
常

Part I

GT $0.25 \mathrm{~g} 100 \mathrm{~mL}^{-1 / 20}$ A $\ldots . . . \mathrm{GT} 0.5 \mathrm{~g} 100 \mathrm{~mL}-1 / 20 "$
$-=\mathrm{GT} 1.0 \mathrm{~g} 100 \mathrm{~mL}-1 / 20$ $\mathrm{B}_{\mathrm{B}}$ $700-1$
$600-1$
500
$400-$
300 $+1$ ind A
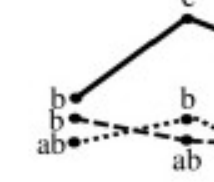

1

orage (Days)
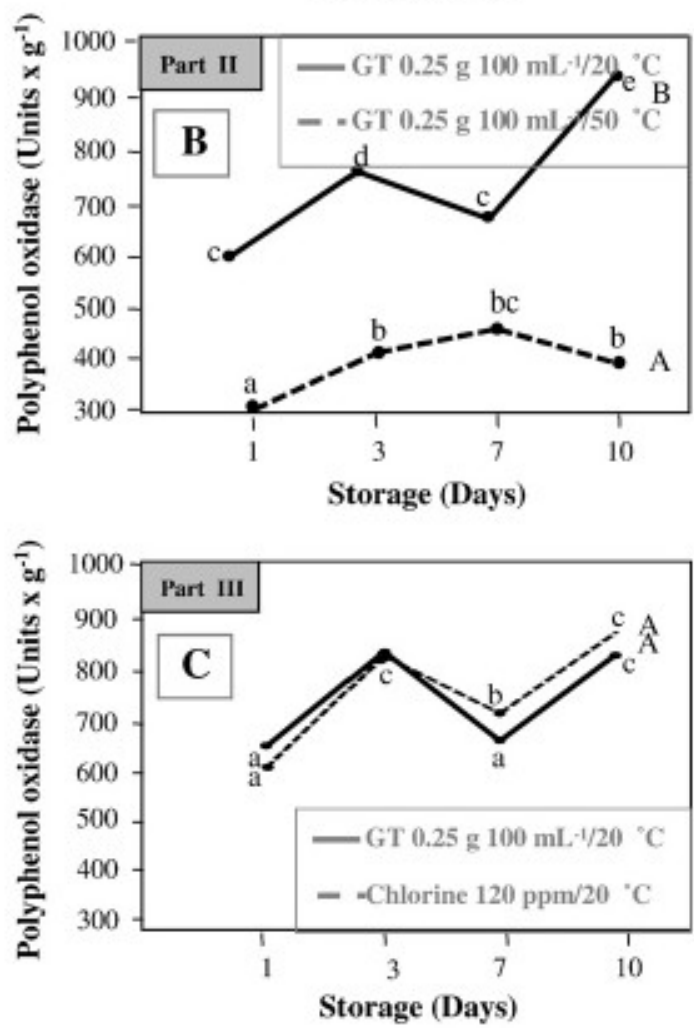

"Points designated on any curve by the same letter are not significantly different $(\mathrm{p}>0.05)$

Fig. 7. Changes in polyphenol oxidase enzymatic activity (PPO, units g- 1 ) in fresh-cut lettuce stored at $4{ }^{\circ} \mathrm{C}$ for 10 days. Part I: GT at different concentrations $(0.25,05$ and $1 \mathrm{~g}$ $100 \mathrm{~mL}-1$ at $20^{\circ} \mathrm{C}$ ). Part II: $0.25 \mathrm{~g} 100 \mathrm{~mL}-1 \mathrm{GT}$ at $20^{\circ} \mathrm{C}$ and $50^{\circ} \mathrm{C}$. Part III: $0.25 \mathrm{~g} 100 \mathrm{~mL}-1$ GT at $20^{\circ} \mathrm{C}$ and $120 \mathrm{ppm}$ chlorine at $20^{\circ} \mathrm{C}$.
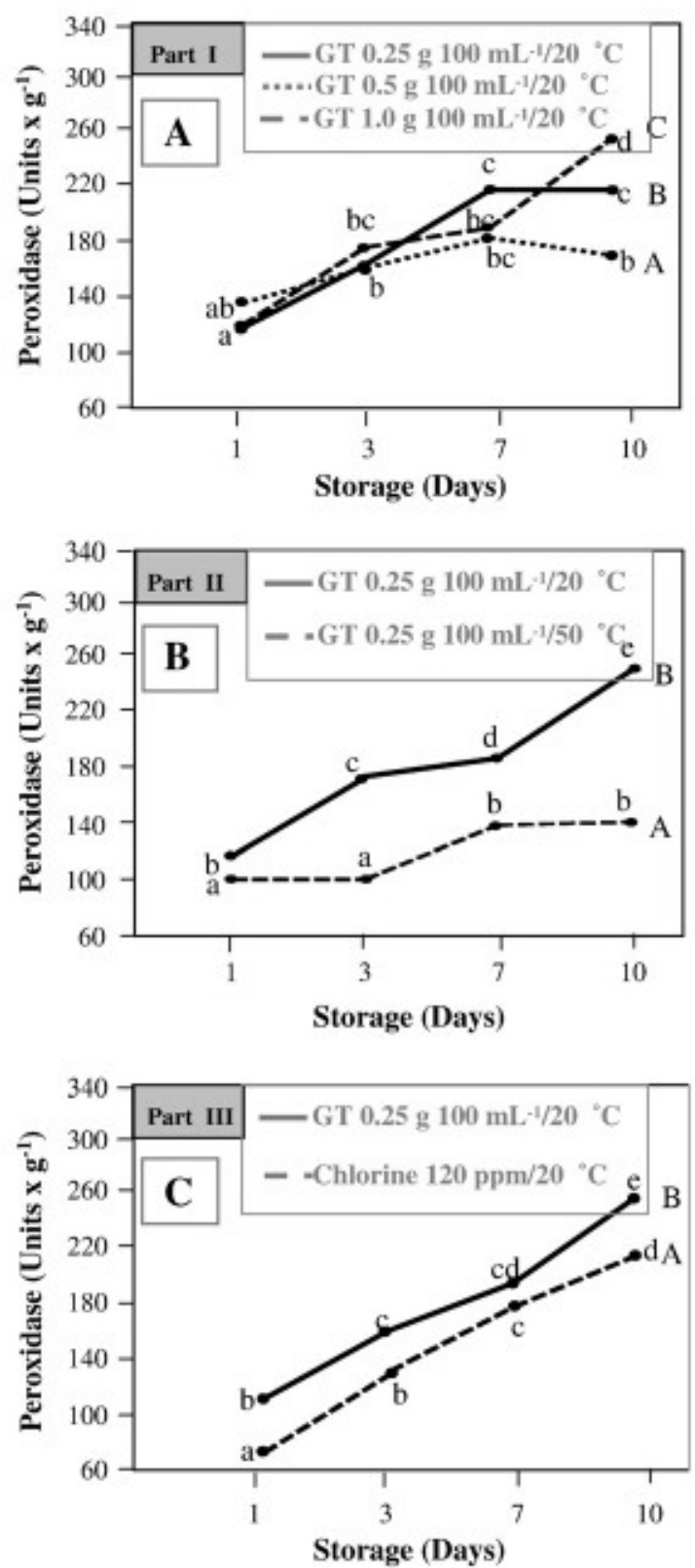

*Points designated on any curve by the same letter are not significantly different $(p>0.05)$

Fig. 8. Changes in peroxidase enzymatic activity (POD, units g-1) in fresh-cut lettuce stored at $4{ }^{\circ} \mathrm{C}$ for 10 days. Part I: GT at different concentrations $(0.25,05$ and $1 \mathrm{~g} 100 \mathrm{~mL}-1$ at $20^{\circ} \mathrm{C}$ ). Part II: $0.25 \mathrm{~g} 100 \mathrm{~mL}-1 \mathrm{GT}$ at $20{ }^{\circ} \mathrm{C}$ and $50{ }^{\circ} \mathrm{C}$. Part III: $0.25 \mathrm{~g} 100 \mathrm{~mL}-1 \mathrm{GT}$ at $20{ }^{\circ} \mathrm{C}$ and $120 \mathrm{ppm}$ chlorine at $20^{\circ} \mathrm{C}$.

Devlieghere, Ragaert, Vanneste \& Debevere, 2003; Gomez-Lopez, Devlieghere, Bonduelle \& Debevere, 2005) have explained this $\mathrm{pH}$ increase with the growth of gram-negative microorganisms, which play an important role in the spoilage of fresh-cut lettuce. Lower GT concentrations kept significantly $(p<0.05)$ lower $\mathrm{pH}$ values during the storage than higher concentrations (Fig. $3 \mathrm{~A}$ ). The lower $\mathrm{pH}$ values at day 10 could respond to an increase in lactic acid bacteria. The samples treated with GT and heat-shock maintained significantly lower produce $\mathrm{pH}$, with no peak observed at day 7 (Fig. 3B). This could be due to the inhibitory effect of temperature on bacterial growth. Delaquis et al. (1999) described a reduction in bacterial counts in lettuce treated with warm water. Similar behaviour was observed in samples treated with chlorine compared with those treated with GT (Fig. 3C). 
Table 1

Sensory evaluation of fresh-cut lettuce using a rating score (1-10) in fresh-cut lettuce stored at $4{ }^{\circ} \mathrm{C}$ for 10 days

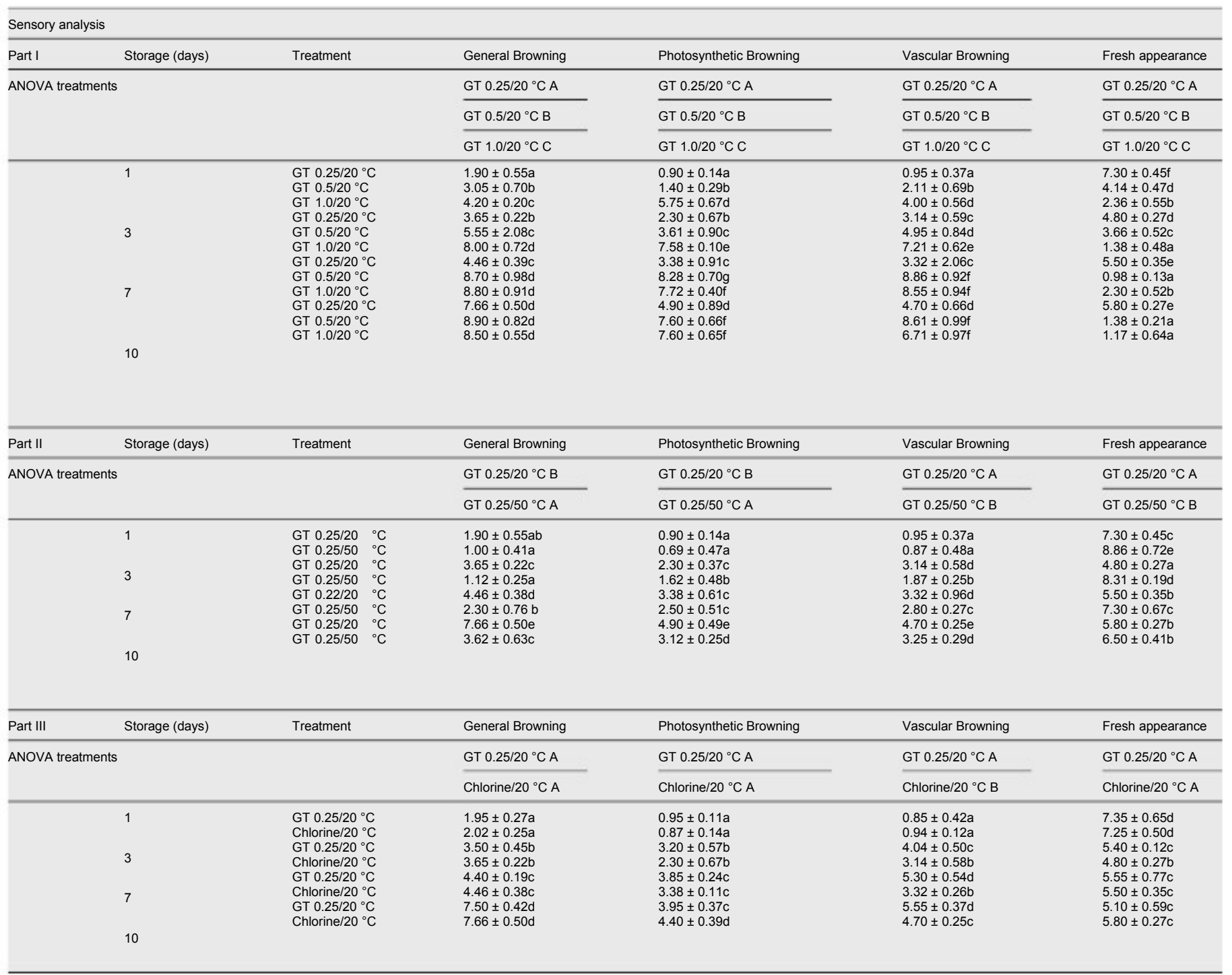

Part I: GT at different concentrations $\left(0.25,05\right.$ and $1 \mathrm{~g} 100 \mathrm{~mL}-1$ at $\left.20^{\circ} \mathrm{C}\right)$. Part II: $0.25 \mathrm{~g} 100 \mathrm{~mL}-1 \mathrm{GT}$ at $20^{\circ} \mathrm{C}$ and $50{ }^{\circ} \mathrm{C}$. Part III: $0.25 \mathrm{~g} 100 \mathrm{~mL}-1 \mathrm{GT}$ at $20{ }^{\circ} \mathrm{C}$ and $120 \mathrm{ppm}$ chlorine at $20{ }^{\circ} \mathrm{C}$.

\subsection{Browning}

\subsubsection{Colour measurement}

Colour was monitored in all the samples during the entire storage (Figs. 4 and 5). Luminosity values $\left(L^{*}\right)$ decreased during storage (Fig. 4A), which can be related to the appearance of browning. The concentration of the treatment (Part I) significantly affected luminosity and increasing GT concentration decreased luminosity values. This might indicate higher browning levels in the lettuce treated with higher GT concentrations. Increasing the temperature of the treatment from $20^{\circ} \mathrm{C}$ to $50{ }^{\circ} \mathrm{C}$ (Part II) resulted in higher luminosity values of the samples (Part II, Fig. 4B), probably due to the inhibitory effect of heatshock on enzymes involved in the enzymatic browning (Saltveit,

2001). Compared with a control treatment (chlorine), GT samples showed lower values in luminosity during the storage (Part III, Fig. 4C). The amount of polyphenols present in the Green tea might have favoured a quicker appearance of browning. Another colour parameter related to browning (Castaner, Gil, Ruiz \& Artes, 1999) and to the breakdown of chlorophyll (Bolin \& Huxsoll, 1991) is $a^{*}$ value. A significant increase in a , indicating a shift from greenness to redness, was observed in all the samples during storage (Fig. 5). GT concentration showed an effect from day 1 on this parameter, increasing a values with increasing concentration (Part I, Fig. 5A). As observed from luminosity results, heat-shock $\left(50^{\circ} \mathrm{C}\right)$ reduced the appearance of browning, which was reflected in lower $\mathrm{a}^{*}$ values during storage (Part II, Fig. 5B). No difference between GT and chlorine samples was observed (Part III, Fig. 5C).

\subsubsection{Potential browning}

Potential browning was monitored in all the samples during storage (Fig. 6). A significant increase of potential browning during storage was observed $(p<0.05)$. This increase in the concentration of phenolic compounds is caused by the wounding stress from the treatment (Hanotel, Fleuriet \& Boisseau, 1995).

Lower potential browning was found in samples treated with the lowest GT concentration (GT $0.25 \mathrm{~g} \mathrm{~L}-1$ ) compared with the other two concentrations $(0.5 \mathrm{~g} 100 \mathrm{~mL}-1$ and $1.0 \mathrm{~g} \mathrm{~L}-1)$ (Part I, Fig. 6A). The combination of GT and heat-shock kept lower potential browning values than GT treatment at room temperature (Part II, Fig. 6B) those results are in agreement with findings from Murata, Tanaka, Minoura and Homma (2004) and Saltveit (2001). Samples treated with chlorine showed higher levels of potential browning than samples treated with 
GT (Part III, Fig. 6C). GT is known for the high antioxidant capacity; however this resulted in a negative effect applied to a commodity affected by browning such as fresh-cut lettuce is, mainly due to the nature of this natural antioxidant. Green tea is rich in polyphenols, which act as substrate for browning-related enzymes.

3.3.3. Browning-related enzymes (peroxidase (POD) E.C.1.11.1.7 and polyphenol oxidase (PPO) E.C.1.10.3.1.)

Browning-related enzymes were measured as indicators of browning in all the samples after treatment and during the 10 days of storage (Fig. 7). A significant increase in PPO was observed during the storage. Samples treated with the highest concentrations of GT $(0.05$ and $1.0 \mathrm{~g}$ $100 \mathrm{~mL}-1$ ) showed lower levels of PPO activity (Part I, Fig. 7A) than samples treated with $0.25 \mathrm{~g} 100 \mathrm{~mL}-1$ GT. These results contrast with those obtained for the other browning markers (Figs. 4A, 5A, 6A and Table 1), showing higher browning incidence in the samples treated with increasing concentrations of GT. Samples treated with the GT at $50{ }^{\circ} \mathrm{C}$ (heat-shock) showed significantly ( $\mathrm{p} \mathrm{b} 0.05$ ) lower PPO activity than those treated with GT at $20^{\circ} \mathrm{C}$ (Part II, Fig. 7B). The inhibition of PPO activity due to heat-shock treatment has been previously reported (Saltveit, 2001). No significant percentage of PPO or POD activity is lost due to the direct effect of the treatment (Martin-Diana et al., 2005c). The reduction in the activity of PPO and POD might be due to an indirect effect caused by feedback inhibition by the lack of phenolic compounds (substrate) or due to a direct effect on a receptor (unknown) implicated

Table 2

Changes in ascorbic acid (mg g-1) in fresh-cut lettuce stored at $4{ }^{\circ} \mathrm{C}$ for 10 days

\begin{tabular}{|c|c|c|c|}
\hline Part I & Storage (days) & Treatment & Ascorbic acid (mg g-1) \\
\hline ANOVA treatments & GT $0.25 / 20^{\circ} \mathrm{C} \mathrm{A}$ & GT $0.5 / 20^{\circ} \mathrm{C} B$ & GT $1.0 / 20^{\circ} \mathrm{C} \mathrm{B}$ \\
\hline & 7 & $\begin{array}{l}\text { GT } 0.25 / 20{ }^{\circ} \mathrm{C} \\
\text { GT } 0.5 / 20{ }^{\circ} \mathrm{C} \\
\text { GT } 1.0 / 20{ }^{\circ} \mathrm{C} \\
\text { GT } 0.25 / 20{ }^{\circ} \mathrm{C} \\
\text { GT } 0.5 / 20{ }^{\circ} \mathrm{C} \\
\text { GT } 1.0 / 20{ }^{\circ} \mathrm{C} \\
\text { GT } 0.25 / 20{ }^{\circ} \mathrm{C} \\
\text { GT } 0.5 / 20{ }^{\circ} \mathrm{C} \\
\text { GT } 1.0 / 20{ }^{\circ} \mathrm{C} \\
\text { GT } 0.25 / 20{ }^{\circ} \mathrm{C} \\
\text { GT } 0.5 / 20{ }^{\circ} \mathrm{C} \\
\text { GT } 1.0 / 20{ }^{\circ} \mathrm{C}\end{array}$ & $\begin{array}{l}0.07 \pm 0.001 d \\
0.07 \pm 0.006 \mathrm{~d} \\
0.8 \pm 0.001 \mathrm{e} \\
0.06 \pm 0.002 \mathrm{c} \\
0.06 \pm 0.001 \mathrm{c} \\
0.07 \pm 0.001 \mathrm{~d} \\
0.05 \pm 0.003 \mathrm{~b} \\
0.06 \pm 0.001 \mathrm{c} \\
0.06 \pm 0.001 \mathrm{c} \\
0.04 \pm 0.002 \mathrm{a} \\
0.05 \pm 0.001 \mathrm{~b} \\
0.05 \pm 0.001 \mathrm{~b}\end{array}$ \\
\hline
\end{tabular}

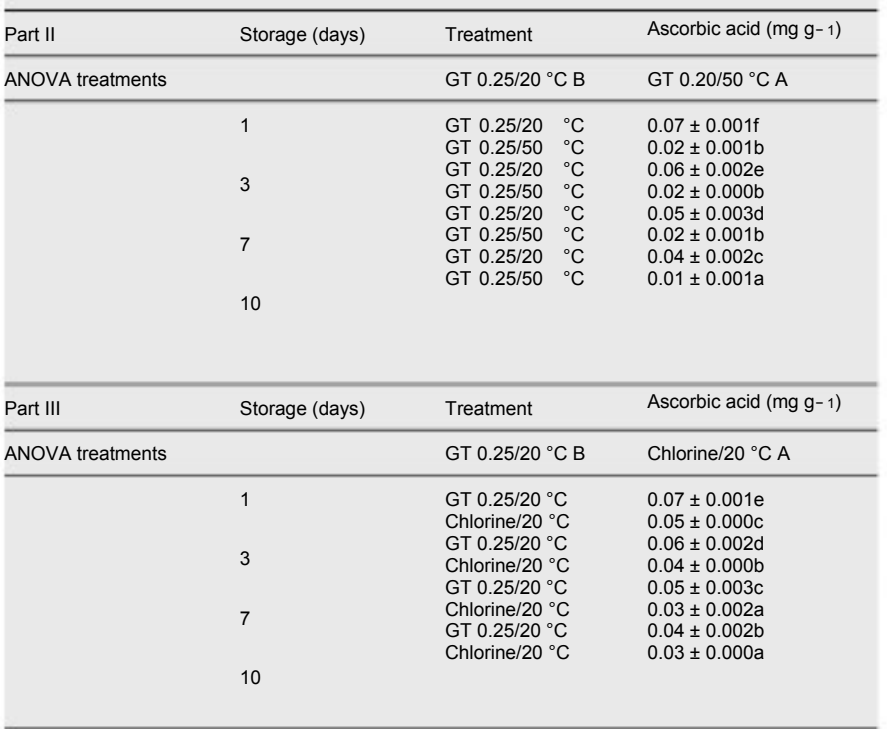

Part I: GT at different concentrations $\left(0.25,05\right.$ and $1 \mathrm{~g} 100 \mathrm{~mL}-1$ at $\left.20^{\circ} \mathrm{C}\right)$. Part II: $0.25 \mathrm{~g}$ $100 \mathrm{~mL}-1 \mathrm{GT}$ at $20^{\circ} \mathrm{C}$ and $50^{\circ} \mathrm{C}$. Part III: $0.25 \mathrm{~g} 100 \mathrm{~mL}-1 \mathrm{GT}$ at $20^{\circ} \mathrm{C}$ and $120 \mathrm{ppm}$ chlorine at $20^{\circ} \mathrm{C}$.
Table 3

Changes in carotenoids (mg g- 1 ) in fresh-cut lettuce stored at $4{ }^{\circ} \mathrm{C}$ for 10 days

\begin{tabular}{|c|c|c|c|}
\hline Part I & Storage (days) & Treatment & Carotenoids (mg g- 1 ) \\
\hline ANOVA treatments & GT $0.25 / 20^{\circ} \mathrm{C} \mathrm{A}$ & GT $0.5 / 20^{\circ} \mathrm{C} \mathrm{B}$ & GT $1.0 / 20^{\circ} \mathrm{C} \mathrm{B}$ \\
\hline & 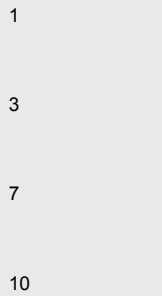 & $\begin{array}{l}\text { GT } 0.25 / 20{ }^{\circ} \mathrm{C} \\
\text { GT } 0.5 / 20{ }^{\circ} \mathrm{C} \\
\text { GT } 1.0 / 20{ }^{\circ} \mathrm{C} \\
\text { GT } 0.25 / 20{ }^{\circ} \mathrm{C} \\
\text { GT } 0.5 / 20{ }^{\circ} \mathrm{C} \\
\text { GT } 1.0 / 20{ }^{\circ} \mathrm{C} \\
\text { GT } 0.25 / 20{ }^{\circ} \mathrm{C} \\
\text { GT } 0.5 / 20{ }^{\circ} \mathrm{C} \\
\text { GT } 1.0 / 20{ }^{\circ} \mathrm{C} \\
\text { GT } 0.25 / 20{ }^{\circ} \mathrm{C} \\
\text { GT } 0.5 / 20{ }^{\circ} \mathrm{C} \\
\text { GT } 1.0 / 20{ }^{\circ} \mathrm{C}\end{array}$ & $\begin{array}{l}0.41 \pm 0.11 a \\
0.99 \pm 0.11 c \\
1.01 \pm 0.13 c \\
0.47 \pm 0.04 a \\
1.01 \pm 0.17 c \\
0.97 \pm 0.14 c \\
0.41 \pm 0.11 a \\
0.70 \pm 0.11 b \\
0.80 \pm 0.13 b \\
0.49 \pm 0.19 a \\
0.77 \pm 0.07 b \\
0.68 \pm 0.06 b\end{array}$ \\
\hline Part II & Storage (days) & Treatment & Carotenoids (mg g- 1 ) \\
\hline \multirow[t]{2}{*}{ ANOVA treatments } & & GT $0.25 / 20^{\circ} \mathrm{C} \mathrm{B}$ & GT $0.25 / 50{ }^{\circ} \mathrm{C} \mathrm{A}$ \\
\hline & $\begin{array}{l}3 \\
7 \\
10\end{array}$ & $\begin{array}{lll}\text { GT } & 0.25 / 20 & { }^{\circ} \mathrm{C} \\
\text { GT } & 0.25 / 50 & { }^{\circ} \mathrm{C} \\
\text { GT } & 0.25 / 20 & { }^{\circ} \mathrm{C} \\
\text { GT } & 0.25 / 50 & { }^{\circ} \mathrm{C} \\
\text { GT } & 0.25 / 20 & { }^{\circ} \mathrm{C} \\
\text { GT } & 0.25 / 50 & { }^{\circ} \mathrm{C} \\
\text { GT } & 0.25 / 20 & { }^{\circ} \mathrm{C} \\
\text { GT } & 0.25 / 50 & { }^{\circ} \mathrm{C}\end{array}$ & $\begin{array}{l}0.41 \pm 0.01 c \\
0.09 \pm 0.02 b \\
0.47 \pm 0.04 c \\
0.07 \pm 0.02 b \\
0.41 \pm 0.01 c \\
0.02 \pm 0.00 a \\
0.49 \pm 0.02 c \\
0.01 \pm 0.01 a\end{array}$ \\
\hline Part II & Storage (days) & Treatment & Carotenoids (mg g- 1 ) \\
\hline \multirow[t]{2}{*}{ ANOVA treatments } & & GT $0.25 / 20^{\circ} \mathrm{C} \mathrm{B}$ & Chlorine $/ 20^{\circ} \mathrm{C} \mathrm{A}$ \\
\hline & $\begin{array}{c}7 \\
10\end{array}$ & $\begin{array}{l}\text { GT } 0.25 / 20^{\circ} \mathrm{C} \\
\text { Chlorine } / 25^{\circ} \mathrm{C} \\
\text { GT } 0.25 / 20^{\circ} \mathrm{C} \\
\text { Chlorine } / 25^{\circ} \mathrm{C} \\
\text { GT } 0.25 / 20^{\circ} \mathrm{C} \\
\text { Chlorine } / 25^{\circ} \mathrm{C} \\
\text { GT } 0.25 / 20^{\circ} \mathrm{C} \\
\text { Chlorine } / 25^{\circ} \mathrm{C}\end{array}$ & $\begin{array}{l}0.41 \pm 0.01 d \\
0.31 \pm 0.01 b \\
0.47 \pm 0.04 d \\
0.35 \pm 0.03 c \\
0.41 \pm 0.01 d \\
0.36 \pm 0.02 c \\
0.49 \pm 0.01 d \\
0.24 \pm 0.04 a\end{array}$ \\
\hline
\end{tabular}

Part I: GT at different concentrations $\left(0.25,05\right.$ and $1 \mathrm{~g} 100 \mathrm{~mL}-1$ at $\left.20^{\circ} \mathrm{C}\right)$. Part II: $0.25 \mathrm{~g}$ $100 \mathrm{~mL}-1 \mathrm{GT}$ at $20^{\circ} \mathrm{C}$ and $50^{\circ} \mathrm{C}$. Part III: $0.25 \mathrm{~g} 100 \mathrm{~mL}-1 \mathrm{GT}$ at $20^{\circ} \mathrm{C}$ and $120 \mathrm{ppm}$ chlorine at $20^{\circ} \mathrm{C}$

in the synthesis of PPO and POD. No differences between samples treated with chlorine and GT $0.25 \mathrm{~g} \mathrm{~L}-1$ (Part III, Fig. 6C) were found.

The GT controlled significantly ( $p$ b 0.05) the POD activity (Fig. 8, Part A). Higher levels of GT inhibited better the POD than lower GT levels. The temperature increase produced an inhibitory effect on this enzyme when the treatment was combined with GT $0.25 \mathrm{~g} 100 \mathrm{~mL}-1$ (Part II, Fig. 8B). Lower levels of POD activity were observed in samples treated with GT than in chlorinated samples (Part III, Fig. 8C). This inhibitory effect responds to the antioxidant capacity of the catechines, the main polyphenol compounds in GT, which can act as free radical-scavengers, quenching hydroxyl radicals $(-\mathrm{OH})$ or superoxide anion radicals (O-) (Hanasaki, Ogawa \& Fukui, 1994; Sichel,2 Corsaro, Scalia, Bilio \& Bonomo, 1991; Aoshima, \& Ayabe, 2007). In contrast with PPO, the polyphenols are not specific subtracts of the POD enzyme.

\subsection{Sensory analysis}

Browning in photosynthetic and vascular tissues, general levels of browning and fresh appearance of the samples were evaluated by the sensory panel. The panel found differences in browning between samples treated with different GT concentrations. Increasing GT concentrations produced more visual browning on the samples and differences between treatments were observed throughout the storage (Table 1, Part I). Scores for fresh appearance also showed the unsuitability of high GT concentrations $(0.5$ and $1.0 \mathrm{~g} 100 \mathrm{~mL}-1)$ 
compared with $0.25 \mathrm{~g} 100 \mathrm{~mL}-1 \mathrm{GT}$. Samples treated with GT and heatshock showed less browning (Table 1, Part II). No differences between chlorine and GT-treated samples were observed (Table 1, Part III). Fresh appearance of samples treated with GT at $0.25 \mathrm{~g} 100 \mathrm{~mL}-1$ or chlorine received higher scores than samples treated with GT at higher concentrations, due mainly to the presence of browning.

\subsection{Nutritional markers}

\subsubsection{Ascorbic acid}

A significant ( $\mathrm{p} \mathrm{b}$ 0.05) decrease in ascorbic acid was observed during the storage. Increasing GT concentration showed a protective effect, avoiding ascorbic acid degradation (Table 2, Part I). This effect might be due to the antioxidant capacity of catechines; the aromatic rings with hydroxyl groups possess strong antioxidant properties (Peterson \& Totlani, 2005). A significant $(p<0.05)$ decrease of the ascorbic acid content was observed after the treatment with heatshock and GT (Table 2, Part II), probably due to the low stability of ascorbic acid at high temperatures (Nagy \& Smooth, 1976; Dewanto, Wu, Adom \& Liu, 2002). When small concentrations of GT $(0.25 \mathrm{~g}$ $100 \mathrm{~mL}-1$ ) were compared with chlorine a larger protection effect was observed in the case of GT (Table 2, Part II).

\subsubsection{Carotenoids}

Similar behaviour as the ascorbic acid was observed for carotenoids (Table 3, Part I). Carotenoid concentration significantly ( $\mathrm{p} \mathrm{b} \mathrm{0.05)}$ dropped during the storage in all the treatments. The use of temperature (heat-shock) increased carotenoid degradation (Table 3, Part II). The use of GT $(0.25 \mathrm{~g} 100 \mathrm{~mL}-1)$ resulted in higher carotenoid levels, compared with the chlorine based treatment (Table 3, Part III).

\section{Conclusion}

The use of Green tea extracts, at the lowest concentration tested $(0.25 \mathrm{~g} 100 \mathrm{~mL}-1)$, is a feasible preservation method for minimally processed lettuce. Green tea treatment positively affected the preservation of ascorbic acid and carotenoid content of the samples. However, the use of high GT concentration $(0.5$ or $1.0 \mathrm{~g} 100 \mathrm{~mL}-1)$ resulted in an unacceptable product when evaluated by the sensory panel. Browning appears to be an important factor involved in this negative effect.

Further research involving safety markers would be needed in order to study the efficacy of GT in controlling microorganism spoilage and pathogen growth. The use of GT in combination with other treatments, as for example heat-shock, is recommended by the authors.

\section{Acknowledgements}

This research was supported by a Technological Sector Research grant (2002-2006). The authors would like to thank Karen Roe for the assistance to the group in the laboratory part of the study. Thanks are also extended to Amcor Flexibles Europe (Bristol, UK) for kindly providing the packaging film.

\section{References}

Abreu, M., Beirão-da-Costa, S., Gonçalves, E. M., Beirão-da-Costa, M. L., \& MoldãoMartins, M. (2003). Use of mild heat pre-treatments for quality retention of freshcut 'Rocha' pear. Postharvest Biology and Technology, 30, 153-160.

Agar, I. T., Massantini, R., Hess-Pierce, B., \& Kader, A. A. (1999). Postharvest $\mathrm{CO}_{2}$ and ethylene production and quality maintenance of fresh-cut kiwi slices. Journal of Food Science, 64(3), 433-440.

Allende, A., \& Artes, F. (2003). UV-C radiation as a novel technique for keeping quality of fresh processed 'Lollo Rosso' lettuce. Food Research International, 36, 739-746.

Allende, A., \& Artes, F. (2003). Combined ultraviolet-C and modified atmosphere packaging treatments for reducing microbial growth of fresh processed lettuce. Food Science and Technology, 36, 779-786.

Official methods of analysis (pp. 690)., 16th ed . (1995). Washington, DC: R. Association of Official Analytical Chemists.
Aoshima, H., \& Ayabe, W. S. (2007). Prevention of deterioration of polyphenol-rich beverages. Food Chemistry, 100, 350-355.

Barry-Ryan, C., \& O'Beirne, D. (1999). Ascorbic acid retention in shredded Iceberg lettuce as affected by minimal processing. Journal of Food Science, 64(3), 498-500.

Beaudry, R. M. (1999). Effect of $\mathrm{O}_{2}$ and $\mathrm{CO}_{2}$ partial pressure on selected phenomena affecting fruit and vegetable quality. Postharvest Biology and Technology, 15(3), affecting fo3-303.

Beuchat, L. R. (1998). Surface decontamination of fruits and vegetables eaten raw: A review. Food Safety Unit, World Health Organisation, Brussels, Belgium. WHO/FSF/FOS /98.2. Beuchat, L. R., \& Ryu, J. H. (1997). Produce handling and processing practices. Emerging Diseases, 3, 459-465.

Bolin, H. R., \& Huxoll, C. C. (1991). Effect of preparation procedures and storage parameters on quality retention of salad-cut lettuce. Journal of Food Science, 56, 416-418.

Bozkurt, H. (2006). Utilization of natural antioxidants: Green tea extract and Thymbra spicata oil in Turkish dry-fermented sausage. Meat Science, 73, 442-450.

Bruhn, C. (2000). Food labelling: Consumer needs. In J. Ralph (Ed.), Food labelling. Blanchfield Cambridge: Woodhead Publishing Limited.

Cao, G., Sofic, E., \& Prior, R. L. (1996). Antioxidant capacity of tea and common vegetables. Journal of Agricultural and Food Chemistry, 44, 3426-3431.

Castaner, M., Gil, M. I., Ruiz, M. V., \& Artes, F. (1999). Browning susceptibility of minimally processed Baby and Romaine lettuces. European Food Research Technology, 209, 52-56

Cherry, J. P. (1999). Improving the safety of fresh produce with antimicrobials. Food Technology, 53, 54-59.

Cooper, R., Morre, J., \& Morre, D. (2005). Medicinal benefits of green tea: Part II. Review of anticancer properties. Journal of Alternative and Complementary Medicine, 11(4), 639-652.

Delaquis, P. J., Stewart, S., Toivonen, P. M. A., \& Moyls, A. L. (1999). Effect of warm, chlorinated water on the microbial flora of shredded iceberg lettuce. Food Research International, 32, 7-14.

Dewanto, V., Wu, X., Adom, K. K., \& Liu, R. F. (2002). Thermal processing enhances the nutritional value of tomatoes by increasing total antioxidant activity. Journal of Agricultural and Food Chemistry, 50, 3010-3014.

Galeazzi, M. A. M., Sgarbieri, V. C., \& Constantinides, S. M. (1981). Isolation, purification and physicochemical characterization of poliphenolxidases (PPO) from dwarf variety of banana (Musa cavendishii, L). Journal of Food Science, 46, 150-155.

Garcia, E., \& Barrett, D. M. (2002). Preservative treatments for fresh-cut fruits and vegetables. In O. Lamikanra (Ed.), Fresh-cut fruits and vegetables. Science, technology and market Boca Raton, Florida: CRC Press.

García, A., Mount, J. R., \& Davison, P. M. (2003). Ozone and chlorine treatment of minimally processed lettuce. Food Microbiology and Safety, 68(9), 2747-2751

Giner, J., Gimeno, V., Espachs, A., Elez, P., Barbosa-Cánovas, G. V., \& Martín, O. (2000). Inhibition of tomato (Lycopersicon esculentum Mill.) pectin methylesterase pulsed electric fields. Innovative Food Science \&Emerging Technologies, 1, 57-67.

Gomez-Lopez, V. M., Devlieghere, F., Bonduelle, V., \& Debevere, J. (2005). Intense light pulses decontamination of minimally processed vegetables and their shelf-life. International Journal of Food Microbiology, 103, 75-89.

Graham, N. J. D. (1997). The role of ozone and potassium permanganate in drinking water treatment. 3rd international workshop on drinking water quality management and treatment technology, 5-6 March. Taipei, Taiwan.

Gramza-Michalowska, A. G., \& Regula, J. (2007). Use of tea extracts (Camelia sinensis) in jelly candies as polyphenols sources in human diet. Asian Pacific Journal of Clinical Nutrition, 16, 43-46.

Gross, J. (1991). Carotenoids. Pigments in vegetables: Chlorophyllase and carotenoids (pp. 124-128). New York: Van Nostrand Reinhold.

Guilbert, S., Gontard, N., \& Gorris, L. (1996). Prolongation of the shelflife of perishable food products using biodegradable films and coating. LWT Food Science and Technology, 29, 10-17.

Hamilton-Miller, J. M. (1995). Antimicrobial properties of tea (Camellia sinensis L.) Antimicrobial Agents and Chemotherapy, 39, 2375 .

Hamilton-Miller, J. M., \& Shah, S. J. (2005). Medicinal benefits of green tea: Part I. Review of noncancer health benefits. Journal of Alternative and Complementary Medicine, 11(3), 521-528.

Han, J., Gomes-Feitosa, C. L., Castell-Perez, E., Moreira, R. G., \& Silva, P. F. (2004). Quality of packaged romaine lettuce hearts exposed to low-dose electron beam irradiation. Food Science and Technology, 37, 705-715.

Hanasaki, Y., Ogawa, S., \& Fukui, S. (1994). The correlation between active oxygens scavenging and antioxidative effects of flavonoids. Free Radical Biology \& Medicine, 16 845-850.

Hanotel, L., Fleuriet, A., \& Boisseau, P. (1995). Biochemical changes involved in browning of c-irradiated cut witloof chicory. Postharvest Biology and Technology, 5, 199-210.

zumi, H. (1999). Electrolyzed water as a disinfectant for fresh-cut vegetables. Journal of Food Science, 64, 536-539

Jacxsens, L., Devlieghere, F., Ragaert, P., Vanneste, E., \& Debevere, J. (2003). Relation between microbiological quality, metabolite production and sensory quality of equilibrium modified atmosphere packaged fresh-cut produce. International Journal of Food Microbiology, 83, 263-280.

Kabir, H. (1994). Fresh-cut vegetables. In A. L. Brods, \& V. A. Herndon (Eds.), Modified atmosphere food packaging (pp. 155-160). : Institute of Packaging Professionals.

Kato-Noguchi, H., \& Watada, A. E. (1997). Citric acid reduces the respiration of fresh-cut carrots. Hortscience, 32,136

Kaur, C., \& Kapoor, H. C. (2001). Antioxidants in fruits and vegetables the millenium's health. International Journal of Food Science and Technology, 36, 703-725. ays, S. J. (1991). Postharvest physiologycal of perishable plant products. New York: Van Nostrand Reinhold.

King, A. D., \& Bolin, H. R. (1989). Physiological and microbiological storage stability of minimally processed fruits and vegetables. Food Technology, 43, 132-135. 
Klein, B. P. (1987). Nutritional consequences of minimal processing on fruits and vegetables. Journal of Food Quality, 10, 179-193.

Koseki, S., Yoshida, K., Kamitani, Y., Isobe, S., \& Itoh, K. (2004). Effect of mild heat pretreatment with alkaline electrolyzed water on the efficacy of acidic electrolyzed water against Escherichia coli O157:H7 and Salmonella on lettuce. Food Microbiology, 21(5), against Esche.

Koukounaras, A., Diamantidis, G., \& Sfakiotakis, E. (2008). The effect of heat treatment on quality retention of fresh-cut peach. Postharvest Biology and Technology, 48 , 30-36.

Lamikanra, O. (2002). Preface. In O. Lamikanra (Ed.), Fresh-cut fruits and vegetables. Science, technology and market CRC Press: Boca Raton, Florid

Loaiza-Velarde, J., Mangrich, M., Campos-Vargas, R., \& Saltveit, M. (2003). Heat shock reduces browning of fresh-cut celery petioles. Postharvest Biology and Technology, $27,305-311$

Luna-Guzmán, I., \& Barrett, D. M. (2000). Comparison of calcium chloride and calcium lactate effectiveness in maintaining shelf stability and quality of fresh-cut cantaloupes. Postharvest Biology and Technology, 19(1),61-72.

Martin-Diana, A. B., Rico, D., Barry-Ryan, C., Frias, J. M., Mulcahy, J., \& Henehan, G. T. M. (2005). Comparison of calcium lactate with chlorine as a washing treatment for fresh-cut lettuce and carrots: Quality and nutritional parameters. Journal of the Science of Food and Agriculture, 85, 2260-2268.

Martín-Diana, A. B., Rico, D., Barry-Ryan, C., Frías, J. M., Mulcahy, J., \& Henehan, G. T. M. (2005). Comparison of calcium lactate with chlorine as a washing treatment fo minimally processed lettuce and carrots: Quality and nutritional markers. Journal of the Science of Food and Agriculture, 85(13), 2260-2268.

Martin-Diana, A. B., Rico, D., Frias, J. M., Barry-Ryan, C., Mulcahy, J., \& Henehan, G. T. M. (2005). Effect of heat-shock on browning-related enzymes in minimally processed iceberg lettuce and crude extracts. Bioscience, Biotechnology and Biochemistry, 69(8), 2131-2139.

Martín-Diana, A. B., Rico, D., Frías, J., Mulcahy, J., Henehan, G. T. M., \& Barry-Ryan, C. (2006). Whey permeate as a bio-preservative for shelf life maintenance of fresh-cut vegetables. Innovative Food Science \& Emerging Technologies, 7, 112-123.

Martín-Diana, A. B., Rico, D., Barry-Ryan, C., Frías, J. M., Henehan, G. T. M., \& Barat, J. M. (2007). Efficacy of steamer jet-injection as alternative to chlorine in fresh-cut lettuce. Postharvest Biology Technology, 45(1), 97-107.

Martín-Diana, A. B., Rico, D., Henehan, G. T. M., Frías, J., Barat, J. M., \& Barry-Ryan, C. (2007). Calcium for extending the shelf-life of fresh whole and minimally processed fruits and vegetables: A review. Trends in Food Science \& Technology, 18(4), 210-218.

McKay, D. L., \& Blumberg, J. B. (2002). The role of tea in human health: An update. Journal of the American College of Nutrition, 21(1), 1-13

Masuda, T., Inaba, Y., Maekawa, T., Takeda, Y., Yamaguchi, H., Nakamoto, K., Kuninaga, H., Nishizato, S., \& Nonaka, A. (2003). Simple detection method of powerful antiradical compounds in the raw extract of plants and its application for the identification of antiradical plant constituents. Journal of Agricultural and Food Chemistry, 51 1831-1838.

Molnar-Perl, I., \& Friedman, M. (1990). Inhibition of browning by sulphur amino acids. 3. Apples and potatoes. Journal of Agricultural and Food Chemistry, 38(8), 1652-1656.

Murata, M., Tanaka, E., Minoura, E., \& Homma, S. (2004). Quality of cut lettuce treated by heat shock: Prevention of enzymatic browning, repression of phenylalanine heat shock: Prevention of enzymatic browning, repression of phenylalanine ammonia-lyase activity, and improvement of sensory evalua

Nagy, S., \& Smooth, J. M. (1976). Temperature and storage effects on percent retention and percent U.S. recommended dietary allowances of vitamin C in canned singlestrength orange juice. Journal of Agricultural and Food Chemistry, 25(1), 135-138.

Nissen, L. R., Byrne, D. V., Bertelsen, G., \& Skibsted, L. H. (2004). The antioxidative activity of plant extracts in cooked pork patties as evaluated by descriptive sensory profiling and chemical analysis. Meat Science, $68,485-495$
O ' Beirne, D., \& Francis, G. A. (2003). Reducing the pathogen risk in MAP-prepared produce. In R. Ahvenainen (Ed.), Novel food packaging techniques (pp. 231-286). Combridge UK. Woodhead Publishing Limited/CRC Press LC.

Ohlsson, T. (1994). Minimal processing-preservation methods of the future - An overview. Trends in Food Science and Technology, 5, 341-344.

Park, C. M., Hung, Y. -C., Doyle, M. P., Ezeike, G. O. I., \& Kim, C. (2001). Pathogen reduction and quality of lettuce treated with electrolyzed oxidizing and acidified chlorinated water. Journal of Food Science, 66, 1368-1372.

Peterson, D. G. \& Totlani, V. M. (2005). Influence of flavonoids on the thermal generation of aroma compounds. In F. Shahidi (Ed.), Phenolics in foods and natural generation of aroma compounds. In F. Shahidi (Ed.), Phenolics in

Rico, D., Martín-Diana, A. B., Henehan, J., Frías, G. T. M., \& Barry-Ryan, C. (2006). Effect of ozone and calcium lactate treatments on browning and textured properties of

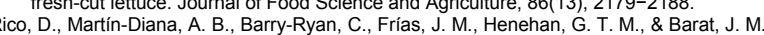
(2008). Optimisation of steamer jet-injection to extend the shelf-life of fresh-cut lettuce. Postharvest Biology Technology, 48(3), 431-442.

Rico, D. Martín-Diana, A. B. Barry-Ryan, C., Frías, J. M., Henehan, G. T. M., \& Barat, J. M. (2008). Use of neutral electrolysed water (EW) for quality maintenance and shelflife extension of minimally processed-lettuce. Innovative Food Science \& Emerging Technologies, 9, 37-48.

Rietveld, A., \& Wiseman, S. (2003). Antioxidant effects of tea: Evidence from human clinical trials. Journal of Nutrition, 133, 3285-3292.

Rosen, J. C., \& Kader, A. A. (1989). Postharvest physiology and quality maintenance of sliced pear and strawberry fruits. Journal of Food Science, 54, 656-659.

Saltveit, M. E. (2001). Wound induced changes in phenolic metabolism and tissue browning are altered by heat shock. Postharvest Biology and Technology, 21, 61-69.

Seymour, I. J. (1999). Review of current industry practice on fruit and vegetable decontamination. Gloucestershire, UK: Campden \& Chorleywood Food Research Association [review no. 14].

Si, W., Gong, J., Tsao, R., Kalab, M., Yang, R., \& Yin, Y. (2006). Bioassay-guided purification and identification of antimicrobial components in Chinese green tea extract. Journal of Chromatography, 1125, 204-210.

Sichel, G., Corsaro, C., Scalia, M., Di Bilio, A. J., \& Bonomo, R. O. (1991). In vitro scavenger activity of some flavonoids and melanin against $\mathrm{O} 2$. Free Radical Biology \& Medicine, 11, 1-8.

Son, S. M., Moon, K. D., \& Lee, C. Y. (2001). Inhibitory effects of various antibrowning agents on apple slices. Food Chemistry, 73, 23-30.

Surjadinata, B. B., \& Cisneros-Zevallos, L. (2003). Modeling wound-induced respiration of fresh-cut carrots (Daucus carots L.). Journal of Food Science, 68, 2735-2740.

an, B. K., \& Harris, N. D. (1995). Maillard products inhibit apple polyphenoxidase. Food Chemistry, 53, 267-273

Wei, C. I., Huang, T. S., Kim, J. M., Lin, W. F., Tamplin, M. L., \& Bartz, J. A. (1995). Growth and survival of Salmonella montevideo on tomatoes and disinfection with chlorinated water. Journal of Food Protection, 58, 829-836.

Varoquaux, P., \& Wiley, R. (1994). Biological and biochemical changes in minimally processed refrigerated fruits and vegetables. In R. C. Wiley (Ed.), Minimally processed refrigerated fruits and vegetables (pp. 226-268). New York: Chapman and Hall.

Viňa, S. Z., \& Chaves, A. S. (2006). Antioxidant responses in minimally processed celery during refrigerated storage. Food Chemistry, 94, 68-74

Yeo, S. G., Ahn, C. W., Lee, Y. W., Lee, T. G., Park, Y. H., \& Kim, S. B. (1995). Antioxidative effect of tea extracts from green tea, oolong tea and black tea. Journal of Korean effect of tea extracts from green tea, oolong

Zhang, L., Zhaoxin, L., Zhifang, Y., \& Xiang, G. (2005). Preservation of freshcut celery by treatment of ozonated water. Food Control, 16, 279-283. 